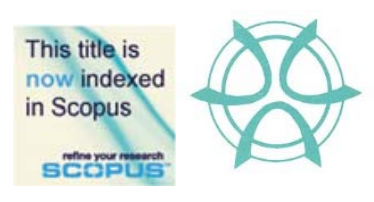

PLANNING MALAYSIA:

Journal of the Malaysian Institute of Planners

VOLUME 16 ISSUE 2 (2018), Page 345 - 352

\title{
INCLUSIVE DISASTER RISK MANAGEMENT (DRM) FOR BERTAM VALLEY COMMUNITY
}

\author{
Rahsidi Sabri Muda ${ }^{1}$, Izawati Tukiman², Mohd Ramzi Mohd Hussain ${ }^{3}$, \& \\ Ismawi Zen ${ }^{4}$ \\ ${ }^{1,2,3}$ Kulliyyah of Architecture and Environmental Design, \\ INTERNATIONAL ISLAMIC UNIVERSITY MALAYSIA
}

${ }^{4}$ AL MADINAH INTERNATIONAL UNIVERSITY

\begin{abstract}
This paper focuses on the inclusiveness of Disaster Risk Management. The study assesses proactive adaptation of Early Warning System (EWS) for Disaster Risk Reduction Program in Bertam Valley. The study aims to identify community preferences as an initiative to improve the effectiveness of the EWS system. In order to sustain the awareness and preparedness of EWS, continuous involvement by the community is necessary to make them resilient. Specific focus is given to Person with Disabilities (PwDs), elderly and children. Therefore, it is vital to understand the efficient methods to alarm PwDs, elderly and children during emergencies occurrence, which will focus on the implementation of types of alarm in EWS with regards to the early warning alarm and emergency notification. The finding from this paper is useful to assist local authorities and emergency responder in the formulation of warning and evacuation procedures to save the PwDs if dam failure is imminent.
\end{abstract}

Keyword: disaster risk management (DRM), inclusive, early warning system (EWS), person with disabilities (PwDs), vulnerable community 
Rahsidi Sabri Muda, Izawati Tukiman, Mohd Ramzi Mohd Hussain, \& Ismawi Zen

Inclusive Disaster Risk Management (DRM) for Bertam Valley Community

\section{INTRODUCTION}

The community-based training and awareness program (CBTAP) is a part of the programs that was designed by the dam owner and emergency responders to educate people about the threats from the dam in Bertam Valley (Figure 1) and actions that needs to be taken. During disasters, people with personal limitation face difficulties to cope with the situation. These include people with disabilities (PwDs), older people, people who have been injured or have chronic diseases, women and children. A study by Handicap International (2015) shows that disabled people were not always aware of risk assessment phases. They were the minority of whom often left out when disaster occured. They were left out during consultation and were neglected in the decision-making processes, hence impeding them from understanding the assessment program.

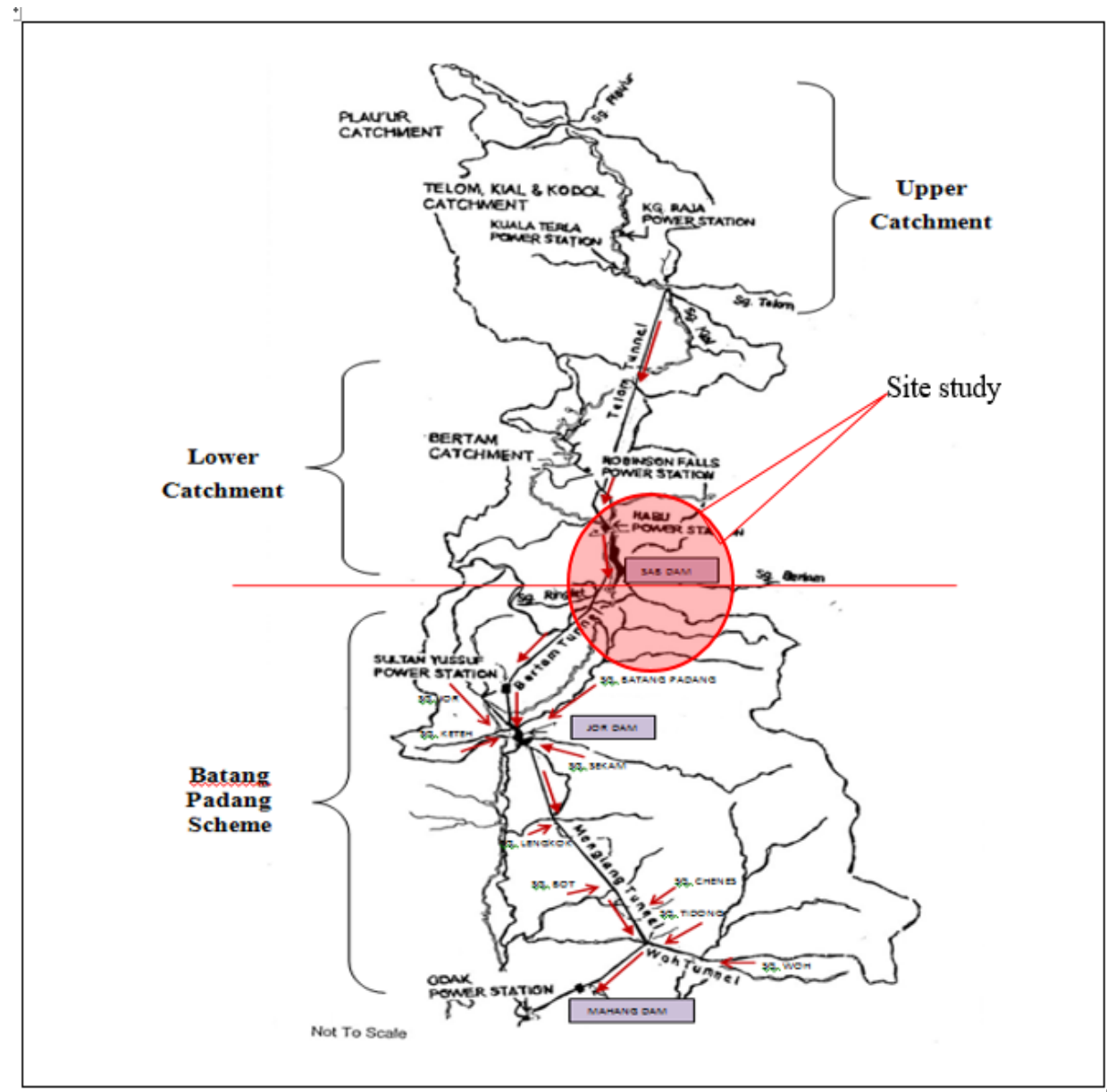

Figure 1: Layout plan for Cameron Highlands - Batang Padang Hydroelectric Scheme. Source: TNBR, 2017 
PLANNING MALAYSIA:

Journal of the Malaysia Institute of Planners (2018)

\section{DISASTER RISK MANAGEMENT IN MALAYSIA}

Aggressive land opening for farming and development has increased the amount of impervious surfaces which resulted to flood during extensive storm event. It has been estimated that over $29,000 \mathrm{~km}^{2}$ or $9 \%$ of the total land area of Malaysia are prone to flood affecting approximately 2.7 million people (Elgilany, Jamalludin, \& Saidatulakmal, 2012). Furthermore, the population growth in developed areas has caused rapid land use changes and contributed to environmental issues. Concentration on the economy in developing countries has left the community lacking in awareness of environmental changes, especially those related to air and water. Over exploitation of natural resources have resulted in increased occurrence of environmental disaster in Malaysia (Haliza, 2014). The implications of environmental disaster have led to chronic environmental changes such as drought, soil erosion and deforestation, and as a result, problem such as flooding has worsen in the last decade and has exposed many population to disaster risk. In addition, the effects of climate change have resulted in an increasing amount of climate related disasters, resulting in a newfound threat to Malaysia's health and development. Recently, it has become a crucial challenge to Malaysia due to several holistic natural disaster events, which gave major impact on economy and finance. However, uncontrolled development activities in watersheds and along river corridors have increased the severity of floods. Cameron Highlands was one of the affected areas due to excessive land encroachment by commercial farmers (Rahsidi, Tukiman, Mohd Hussein, \& Zen, 2007). Therefore, the Malaysian government has adopted UN World Conference global plan for natural disaster risk reduction, the Hyogo Frameworks for Actions (2005-2015) and Sendai Framework (2015-2030). The Sendai Framework for Disaster Risk Reduction (2015-2030) was adopted at the 3rd United Nations World Conference, which represented opportunity for countries; to focus on progressive and action for disaster risk reduction, completing the assessment and review of the implementation the 'Resilience of Nations and Communities to Disasters', strategizing and planning for disaster risk reduction through relevant regional agreements, identifying modalities of cooperation based on commitments and periodic review of the implementation of a post 2015 framework for disaster risk reduction. The official UNISDR (2009) definition of Disaster Risk Management is:

"The systematic process of using administrative directives, organizations, and operational skills and capacities to implement strategies, policies and improved coping capacities in order to lessen the adverse impacts of hazards and the possibility of disaster."

Therefore, Inclusive DRM (including DRR processes) is the right for those who are most at risk to benefit from and participate, as an actor, in all Disaster Risk Management policies and practices. 
Rahsidi Sabri Muda, Izawati Tukiman, Mohd Ramzi Mohd Hussain, \& Ismawi Zen

Inclusive Disaster Risk Management (DRM) for Bertam Valley Community

\section{RESILIENCE CITY FOR RESILIENCE PWDS}

People with disabilities (PwDs) is among the minorities of humankind, and recent studies suggest that people with disabilities represent 10 to $12 \%$ of the world's population (Mont, 2007). Mont (2007) also highlighted that $85 \%$ of PwDs do not participated in community DRR processes.

In 2007, the World Bank issued a Guidance Note to incorporate disability criteria into its supported projects. The guidelines recommended integration on social analysis of disability in the design of thematic and sector projects and programs. Particularly regarding community driven development (CDD). The guidelines focus on inclusion of PwDs within the broader project cycle.

Disasters cause a bigger impact on those who are disabled, due to lack of access to information and services (ARUP International Development, 2012). In countries with poor structural development and scarcity of resources, the impact of natural disasters on PwDs is devastating. The loss of family members, homes, and livelihoods in the aftermath of a disaster particularly affect such individuals. Most of the temporary shelter are not equipped with proper access of supplies and proper assistance for the PwDs.

\section{INCLUSIVE EARLY WARNING SYSTEM IN BERTAM VALLEY}

Early Warning System (EWS) is the provision of information to individuals, households, groups or a community about the existence of danger or hazard, and what can be done to prevent, avoid or minimize the danger. They are also to advice on the means of protection and preparedness on how to deal with the impending hazards. There are different mediums that can be used to disseminate information on EWS (Table 1).

Table 1: Types of disabilities and warning systems

\begin{tabular}{|c|c|}
\hline Types of disabilities & Warning systems \\
\hline Visual disabilities & $\begin{array}{l}\text { - } \\
\text { - Auditory signal system / alarms } \\
\text { - } \\
\text { Posters written with large characters and colour } \\
\text { contrast }\end{array}$ \\
\hline Hearing disabilities & $\begin{array}{ll}\text { - } & \text { Visual signal systems - red flag, symbols } \\
\text { - } & \text { Pictures }\end{array}$ \\
\hline Intellectual disabilities & $\begin{array}{ll}\text { - } & \text { Turn light off and on frequently } \\
\text { - } & \text { Special signals - red flag, symbols } \\
\text { - } & \text { Clear and brief announcements by rescue workers }\end{array}$ \\
\hline Physical disabilities & $\begin{array}{ll}\text { - } & \text { Auditory signal system / alarms } \\
\text { - } & \text { Announcements }\end{array}$ \\
\hline
\end{tabular}

Source: The World Bank, 2008 
Based on the World Bank (2008) key principles to inclusive disaster risk management that can be considered to suit Malaysia community, are:

- Non-discrimination - According to international law, people with disabilities must have the same opportunities to benefit from CBTAP and DRR program provided by dam owner. In UN Convention on the Rights of Persons with Disabilities requires equal access for, and prohibits discrimination against, people with disabilities in all aspects of life and establishes the obligation to ensure the protection and safety of all people with disabilities in situations of risk, including natural disasters.

- Accessibility: People with disabilities should be able to enter and use facilities and gain access to the mainstreamed programs, services, and activities that are provided by dam owner. Notification of emergencies, evacuation, transportation, communication, shelter, distribution of supplies, food, first aid, medical care, housing, and application for and distribution of benefits should be accessible for people with disabilities on an equal basis with others.

- Involving people with disabilities and their organizations in all stages of a community driven disaster management: People with disabilities are the most knowledgeable about their own needs and best to be referred for the inclusiveness of the whole EWS program.

- Appropriate early warning systems: Disabled people can gives opinion on the design of an early warning and information, education, and communication systems. The development of early warnings in a disabledfriendly may include various multi-model warning means (visual signs or signals, auditory alarms, peer support, community support, etc.), which, adapted to local conditions, and contribute to a wider dissemination and communication of risk information.

\section{METHODS}

The study opted for qualitative and quantitative method. As for qualitative method, an observation was conducted during a site visit to Bertam Valley and three Orang Asli villages, which is $\mathrm{Kg}$. Sg. Tiang, Kg. Mensun and Kg. Leryar. The observation recorded the various aspect of EWS that have been installed on site, such as the location, distant from one alarm to another alarm, and signages. In order to identify the obstacle that might incurred in many community-based programs, an interview has been conducted to obtain additional data, especially on the technical and operation of a EWS system and procedure during disaster. Qualitative method using questionnaire survey as its tools, which it has been designed by including the demographic data, information on community-based programs or activities and their preference of EWS. 
Rahsidi Sabri Muda, Izawati Tukiman, Mohd Ramzi Mohd Hussain, \& Ismawi Zen

Inclusive Disaster Risk Management (DRM) for Bertam Valley Community

\section{COMMUNITY PREFERENCE OF EWS}

Table 2 shows that respondent agreed with the effectiveness of EWS in delivering the warnings through the means of siren $(M=4.70)$, beacon $(M=4.37)$, loudspeaker $(\mathrm{M}=4.12)$, warning marker $(\mathrm{M}=3.13)$, warning from friends or relatives $(M=4.13)$, and warnings from officers/authorities $(M=4.48)$. Flag warning, as according to the result of interview was not applied, but there were some who agreed that it would be great if flag warning could be used as an alternative method since it could really determine whether the situation was critical or not. It was apparent in this case that a functional civic organizations plays an integral role in empowering community and increases their social capacity.

Table 2: The effectiveness of EWS

\begin{tabular}{lccccccc}
\hline Effectiveness of warning system & $\mathbf{1}$ & $\mathbf{2}$ & $\mathbf{3}$ & $\mathbf{4}$ & $\mathbf{5}$ & $\mathbf{M}$ & SD \\
\hline Siren & .4 & 0 & 3.7 & 21.0 & 75.0 & 4.70 & .572 \\
Beacon & 1.3 & 2.6 & 7.7 & 34.4 & 54.1 & 4.37 & .834 \\
Loudspeaker & 3.1 & 4.4 & 12.8 & 36.4 & 43.3 & 4.12 & 1.001 \\
Flag warning & 22.5 & 17.2 & 28.0 & 21.4 & 11.0 & 2.81 & 1.301 \\
Warning marker & 12.6 & 15.9 & 30.0 & 28.5 & 13.0 & 3.13 & 1.205 \\
TV/Radio & 20.7 & 20.1 & 25.4 & 20.8 & 13.0 & 2.85 & 1.318 \\
Electronic messages & 31.6 & 26.3 & 17.2 & 17.6 & 7.3 & 2.43 & 1.292 \\
Social networking & 41.0 & 24.3 & 13.7 & 12.4 & 8.6 & 2.23 & 1.329 \\
Warning from friends and & 2.6 & 2.2 & 12.1 & 45.7 & 37.5 & 4.13 & .893 \\
relatives & .5 & .5 & 7.5 & 32.9 & 58.5 & 4.48 & .707 \\
Warning from officers/authorities & .5 & & & & Total & 3.53 & 1.045 \\
\hline
\end{tabular}

Based on community preference of EWS, the World Bank's types of disabilities and warning systems, and observation on the EWS provided by dam owner, Table 3, proved that the dam owner EWS fulfilled the alarm system to warn PwDs in the event of dam failure in Lembah Bertam and its vicinity. However, continuous staff training for additional skills and assistance woulf strengthen, sustain and improve the overall EWS.

Table 3: Inclusiveness of EWS provided by dam owner

\begin{tabular}{llll}
\hline $\begin{array}{c}\text { Types of } \\
\text { disabilities }\end{array}$ & $\begin{array}{c}\text { Consideration of } \\
\text { EWS (The World } \\
\text { Bank, 2008) }\end{array}$ & \multicolumn{1}{c}{$\begin{array}{c}\text { Community } \\
\text { preference of } \\
\text { EWS }\end{array}$} & $\begin{array}{c}\text { Skills and } \\
\text { assistance }\end{array}$ \\
\hline $\begin{array}{l}\text { Visual } \\
\text { disabilities }\end{array}$ & $\begin{array}{l}\text { Auditory signal system } \\
\text { / alarms }\end{array}$ & Siren & \\
\cline { 2 - 4 } & Announcements & $\begin{array}{l}\text { Instruction by } \\
\text { community leader (Tok } \\
\end{array}$ & \\
& & Batin, JKKK) and \\
\hline
\end{tabular}


PLANNING MALAYSIA:

Journal of the Malaysia Institute of Planners (2018)

\begin{tabular}{|c|c|c|c|}
\hline & & $\begin{array}{l}\text { responsible authorities } \\
\text { (JPA, police, etc.) }\end{array}$ & \\
\hline & $\begin{array}{l}\text { Posters written with } \\
\text { large characters and } \\
\text { colours contrast }\end{array}$ & Signages & $\begin{array}{l}\text { Leaflet with } \\
\text { Braille to explain } \\
\text { further } \\
\text { information of } \\
\text { 'disaster shelter } \\
\text { program' }\end{array}$ \\
\hline \multirow[t]{3}{*}{$\begin{array}{l}\text { Hearing } \\
\text { disabilities }\end{array}$} & $\begin{array}{l}\text { Visual signal systems } \\
\text { - red flag, symbols }\end{array}$ & Beacons (flash lights) & \\
\hline & Pictures & Signages & \\
\hline & & $\begin{array}{l}\text { Responsible person in } \\
\text { charged }\end{array}$ & $\begin{array}{l}\text { Ability to } \\
\text { communicate in } \\
\text { basic sign } \\
\text { language. }\end{array}$ \\
\hline \multirow[t]{3}{*}{$\begin{array}{l}\text { Intellectual } \\
\text { disabilities }\end{array}$} & $\begin{array}{l}\text { Turn light off and on } \\
\text { frequently }\end{array}$ & Siren and beacons & \\
\hline & $\begin{array}{l}\text { Clear and brief } \\
\text { announcements by } \\
\text { rescue workers }\end{array}$ & $\begin{array}{l}\text { Instruction by } \\
\text { community leader (Tok } \\
\text { Batin, JKKK) and } \\
\text { responsible authorities } \\
\text { (JPA, police, etc.) }\end{array}$ & \\
\hline & $\begin{array}{l}\text { Special signals - red } \\
\text { flag, symbols }\end{array}$ & Signages with symbols & $\begin{array}{l}\text { Symbols to be } \\
\text { introduce to } \\
\text { PwDs }\end{array}$ \\
\hline \multirow[t]{2}{*}{$\begin{array}{l}\text { Physical } \\
\text { disabilities }\end{array}$} & $\begin{array}{l}\text { Auditory signal system } \\
\text { / alarms }\end{array}$ & Siren and beacons & \\
\hline & Announcements & $\begin{array}{l}\text { Instruction by } \\
\text { community leader (Tok } \\
\text { Batin, JKKK) and } \\
\text { responsible authorities } \\
\text { (JPA, police, etc.) }\end{array}$ & \\
\hline
\end{tabular}

\section{CONCLUSION}

The dam owner has taken into consideration of inclusiveness in the design of its EWS program as a whole. This is to support Malaysia commitment to the 'Sendai Framework' for Disaster Risk Reduction, which a continuous support from 'Hyogo Framework' for Action. The CBTAP program also met the UN Convention on the Rights of Persons with Disabilities (CRPD), Articles 11 and 32 require that persons with disabilities benefit from and participate in disaster relief, emergency response and Disaster Risk Reduction strategies. Dam owner had put their initiative by providing training for stakeholder and agencies that involved during dam failure. In addition, information was also disseminated to 
Rahsidi Sabri Muda, Izawati Tukiman, Mohd Ramzi Mohd Hussain, \& Ismawi Zen

Inclusive Disaster Risk Management (DRM) for Bertam Valley Community

community through various programs such as educational activities in schools within the affected areas. The inclusiveness of CBDRM program will be continuous improved by involving respected PwDs associations in the future to provide specialist inputs.

\section{ACKNOWLEDGEMENT}

The authors would like to thank the Tenaga Nasional Research Sendirian Berhad (TNBR) for their kind support by giving useful information and advice on conducting the research. This paper was a result from research grant collaboration between IIUM-UNITEN and TNBR.

\section{REFERENCES}

ARUP International Development (2012). Characteristic of a safe and resilient community: Community based disaster risk reduction study. Retrieved from http://www.ifrc.org/PageFiles/96986/Final_Characteristics_Report.pdf.

Elgilany, A., Jamalludin S., \& Saidatulakmal M. (2012). Importance of floods management in Malaysia. International Conference on Environmental Research and Technology (ICERT) 2012. Penang, Malaysia.

Haliza, A. R. (2014). An overview of environmental disaster in Malaysia and preparedness strategist. Iranian Journal of Public Health, 43(3), 17-24.

Handicap International (2015). Inclusive disaster risk reduction post 2015: Handicap International expertise. Retrieved from http://www.handicapinternational.ch/sites/ch/files/documents/files/inclusive_disaster_risk_reduction _post201_hi_expertise.pdf

Mont, D. (2007). Measuring disability prevalence. Washington DC: The World Bank.

Rahsidi, S. M., Tukiman, I., Mohd Hussein, M. R., \& Zen, I. (2017, October). Perception analysis on public awareness and preparedness towards Early Warning System (EWS) for dam safety: A case study in Bertam Valley Cameron Highlands. HYDRO2017 Conference. October 8-11, 2017, Seville, Spain.

The World Bank (2008). Building the resilient communities. Retrieved from http://siteresources.worldbank.org/INTSF/Resources/Building_Resilient_Com munities_Complete.pdf.

UNISDR. (2009). Terminology on disaster risk reduction. International Strategy for Disaster Reduction (ISDR), 35. 